\title{
1. INTRODUCTION TO THE SCIENTIFIC RESULTS OF LEG 135: LAU BASIN-TONGA RIDGE DRILLING TRANSECT ${ }^{1}$
}

\author{
James W. Hawkins, ${ }^{2}$ Lindsay M. Parson, ${ }^{3}$ and James F. Allan ${ }^{4}$
}

\section{INTRODUCTION}

The Ocean Drilling Program (ODP) devoted eight drilling legs in the western Pacific to the study of convergent plate margins and their associated backarc basins and marginal seas. These drilling programs included transects in the Celebes and Sulu seas, the Izu-Bonin-Mariana region, the Japan Sea, the Nankai Trough, the Vanuatu-New Hebrides region, and the Lau Basin-Tonga Ridge. In this volume we present the scientific results of Leg 135: the Lau Basin-Tonga Ridge drilling transect.

The goal for Leg 135 was to gain a better understanding of the geologic history of the Lau Basin. This is important in understanding the geologic evolution of the Tonga Trench convergent margin as well as the broader problem of the evolution of arc-trench systems and backarc basins. A major objective was to assess the relationship between subduction processes and petrologic-tectonic processes in the forearc, arc, and backarc. These were identified as major thematic objectives in the COSOD Science Plan (JOI, 1981) and the COSOD II Plan (JOI-ESF, 1987). The latter recognized a need for "clearer documentation of the interaction between such (arc and backarc) magma types both spatially and with time in the development of an arc-backarc system." Specifically, major goals for Leg 135 included understanding the age and composition of the crust of the basin in the region between the remnant arc and the modern spreading ridges, spatial variability in mantle source material for the crust of the backarc basin, the nature and sources of the sedimentary infilling of sub-basins within the Lau Basin, the age and composition of the basement of the Tonga Ridge, and its uplift/subsidence history.

\section{GEOLOGIC SETTING}

The Lau Basin is a backarc basin situated between the Lau Ridge remnant arc and the Tonga Ridge; the latter comprises an active volcanic arc (the Tofua Arc) and a linear chain of uplifted platform carbonate rocks, atoll reefs, and older crystalline basement rocks (Fig. 1). The Tonga Trench lies to the east of the Tonga Ridge and marks the boundary between the Pacific and the Indo-Australian plates. In detail, this boundary is complex as the Lau Basin comprises several microplates separated by spreading ridges and transform faults. The backarc basin has a roughly trapezoidal shape that probably is the result of a progressively younger age for initial opening from north to south. The present rate of subduction of the Pacific Plate relative to the Tonga Ridge varies with latitude from about 16 to $23 \mathrm{~cm} / \mathrm{yr}$ (Pelletier and Louat, 1989). These high rates of convergence are the result of the added east-directed component caused by backarc spreading. Although the Lau-Tonga system clearly is located in a region of litho-

\footnotetext{
'Hawkins, J., Parson, L., Allan, J., et al., 1994. Proc. ODP. Sci. Results, 135: College Station, TX (Ocean Drilling Program).

${ }^{2}$ Geological Research Division, Scripps Institution of Oceanography, La Jolla, CA 92093-0220, U.S.A.

${ }^{3}$ Institute of Oceanographic Sciences, Wormley, Godalming, Surrey GU8 5UB, United Kingdom.

${ }^{4}$ Ocean Drilling Program, Texas A\&M University, 1000 Discovery Drive, College Station, TX 77845-9547, U.S.A.
}

sphere convergence, like many other arc-backarc systems it is dominated by crustal extension.

Plate convergence processes and associated magmatism have been active in the region since early to mid-Eocene time (e.g., Colley and Hindle, 1984; Gill, 1987), as evidenced by occurrences of igneous rocks characteristic of magmagenesis in subduction zone environments (e.g., boninitic and arc-tholeiitic lavas). The oldest remnants of these magma systems are found both on the Tonga Ridge and to the west in the Fiji Islands. Miocene and younger volcanic rocks form the Lau Ridge and the Fiji Islands. The Tofua Arc, on the Tonga Ridge, comprises the youngest belt of arc volcanoes (late Pliocene and younger). The tectonic-magmatic evolution of the Lau Basin began in late Miocene time (about $6 \mathrm{Ma}$ ), contemporary with arc magmatism on the remnant arc (Lau Ridge). The earliest stage of backarc basin opening was accomplished by crustal extension and rifting of the outboard edge of the volcanic arc and its forearc. This formed a series of sub-basins separated by high-standing blocks of ocean crust with arc-like chemistry, and compositions transitional between mid-oceanridge basalt (MORB) and arc. The sub-basins are largely floored with MORB-like lavas, although some have more arc-like material. The sub-basins formed local sediment depocenters filled with both turbiditic clastic material and pelagic sediments. Subsequently (about 4.5-5.0 $\mathrm{Ma})$, the extension and rifting was supplanted by seafloor spreading on a well-defined axial ridge in the central part of the basin. Since about 4.5 Ma, this axial ridge has propagated southward from a point on a ridge that presently acts as a transform fault within the backarc basin. A second southward-propagating rift has followed the first and forms an overlapping spreading center (Parson et al., 1990). The geometry and petrology of the axial ridge systems is well known from extensive work in the region (e.g., Hawkins, 1976; Hawkins and Melchior, 1985; Ernewein et al., in press). The main rock type forming at the axial ridges is close in composition to MORB in most essential chemical and mineralogic characteristics; however, many samples show some affinity to arc-like lavas. Rocks erupted at the southernmost end of the basin, on the Valu Fa Ridge, approach andesitic compositions.

Our drilling results provide further support to previous observations that the crust of backarc basins has many similarities to MORB but that it also displays much heterogeneity, including arc-like and transitional varieties. Our interpretation of the tectonic evolution of the Lau Basin has many similarities to interpretations of the evolution of the Mariana Trough, Izu-Bonin, and Japan Sea (e.g., Taylor, 1992; Tamaki et al., 1992). That is, initial crustal extension and arc rifting was followed by seafloor spreading on propagating axial ridges. However, in detail, each system is distinctive and must reflect original differences in the crustal age and thickness, crustal fabric, and stress fields.

\section{SUMMARY}

The results of Leg 135 provide new insight to the evolution of the Lau Basin; these data complement data from the other western Pacific arc-backarc systems and suggest that many share a broadly similar evolutionary scheme. Although a complete discussion of the results is not intended here, we wish to draw attention to several new findings that have changed our original, relatively simple picture of Lau Basin evolution. 


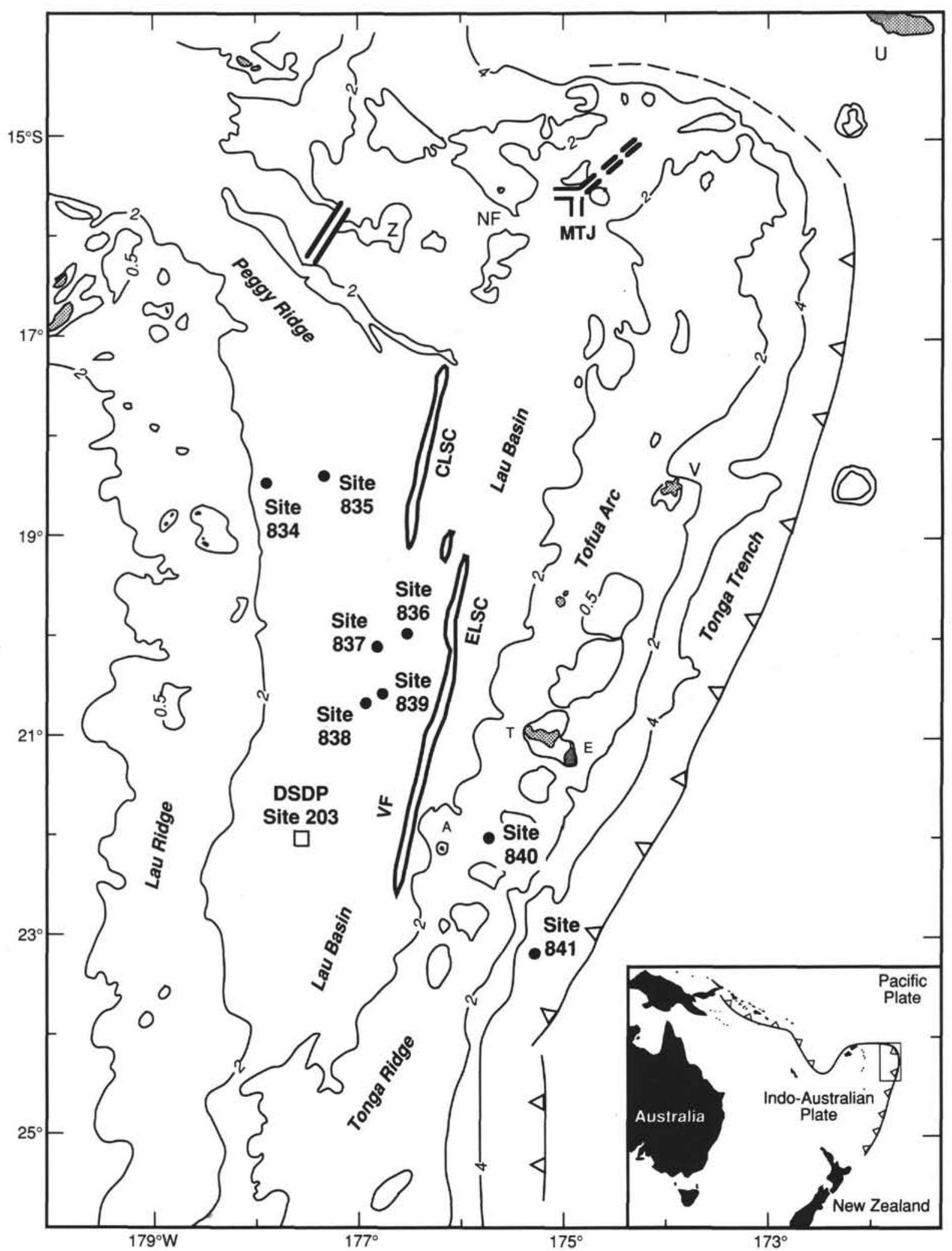

Figure 1. Lau Basin and Tonga trench-arc system showing locations of ODP Leg 135 Sites 834-841 (solid circles) and DSDP Site 203 (open square). Major features shown include sites of modern volcanism in the Lau Basin: Mangatolu Triple Junction (MTJ), Central Lau Spreading Center (CLSC), Eastern Lau Spreading Center (ELSC), and Valu Fa Ridge (VF). Islands and shoals are Niuafo'ou (NF), Zephyr Shoal (Z), Vava'u (V), Tongatapu (T), 'Eua (E), 'Ata (A), and Upolu (U), Western Samoa. Contour interval in kilometers. References for descriptions of physiographic features are in Hawkins (this volume). 
The opening of the Lau Basin is a response to the subduction process at the Tonga Trench, but earlier views that envisioned seafloor spreading as the primary control on crustal generation are not correct. The basin has evolved in two stages: the earliest stage involved crustal extension and rifting that developed basin-range structure; and the second stage, involving seafloor spreading, is a response to southward-propagating rifts that may have originated at an intrabasin transform fault. The crustal extension and rifting were accompanied by local eruption of MORB-like lavas that ponded in the rift basins. As the basin opened, numerous short-lived arc composition volcanoes also formed within the basin. These ephemeral arc edifices were the sources for some of the infilling of the rift basins. The initial rifting was contemporary with rifting and volcanism on the Lau Ridge (remnant arc). The MORB-like magmas are the main magma type that forms crust at the spreading ridges; however, spatial and temporal heterogeneity is present in the composition of the crust.

The basement of the Tonga Ridge includes distal facies of arcderived volcaniclastic turbidites that had their source on the Lau Ridge before the initial opening of the basin. Arc-tholeiitic lavas, intrusive into these sediments, provide evidence for magmatic activity in the former forearc to the Lau Ridge. The oldest rocks yet discovered on the present Tonga Ridge are late-middle Eocene age, low-K rhyolitic flows, tuffs, and breccias that were erupted in a subaerial or shallow-water setting. Their present position at $5200 \mathrm{~m}$ below sea level ( $605 \mathrm{~m}$ below seafloor) indicates great subsidence since their eruption. Their chemistry suggests that they are most likely the differentiates of arc-tholeiitic lavas, although an origin by melting of older basaltic crust is also possible.

\section{REFERENCES}

Colley, H., and Hindle, W.H., 1984. Volcano-tectonic evolution of Fiji and adjoining marginal seas. In Kokelaar, B.P., and Howells, M.F. (Eds.), Marginal Basin Geology: Oxford (Blackwell), 151-162.
Ernewein, M., Pearce, J.A., Bloomer, S.H., Parson, L.M., Murton, B.J., Johnson, L.E., in press. In Smellie, J. (Ed.), Volcanism Associated with Extension at Consuming Plate Margins. Geol. Soc. Spec. Publ. (London).

Gill, J.B., 1987. Early geochemical evolution of an oceanic island arc and backarc: Fiji and the South Fiji Basin. J. Geol., 95:589-615.

Hawkins, J.W., 1976. Petrology and geochemistry of basaltic rocks of the Lau Basin. Earth Planet. Sci. Lett., 28:283-297.

Hawkins, J.W., and Melchior, J.T., 1985. Petrology of Mariana Trough and Lau Basin basalts. J. Geophys. Res., 90:11431-11468.

JOI, 1981. Conference on Scientific Ocean Drilling. Washington (JOI, Inc.).

JOI-ESF, 1987. Report of the Second Conference on Scientific Ocean Drilling. Washington (JOI, Inc.).

Parson, L.M., Pearce, J.A., Murton, B.J., Hodkinson, R.A., Bloomer, S., Ernewein, M., Huggett, Q.J., Miller, S., Johnson, L., Rodda, P., and Helu. S., 1990. Role of ridge jumps and ridge propagation in the tectonic evolution of the Lau back-arc basin, southwest Pacific. Geology, 18:470-473.

Pelletier, B., and Louat, R., 1989. Seismotectonics and present day relative plate motions in the Tonga-Lau and Kermadec-Havre region. Tectonophysics, 165:237-250.

Tamaki, K., Suyehiro, K., Allan, J., Ingle, J.C., Jr., and Pisciotto, K.A., 1992. Tectonic synthesis and implications of Japan Sea ODP drilling. In Tamaki, K., Suyehiro, K., Allan, J., McWilliams, M., et al., Proc. ODP, Sci. Results, 127/128 (Pt. 2): College Station, TX (Ocean Drilling Program), 1333-1348.

Taylor, B., 1992. Rifting and the volcanic-tectonic evolution of the Izu-BoninMariana Arc. In Taylor, B., Fujioka, K., et al., Proc. ODP, Sci. Results, 126: College Station, TX (Ocean Drilling Program), 627-651.

\footnotetext{
- Abbreviations for names of organizations and publication titles in ODP reference lists follow the style given in Chemical Abstracts Service Source Index (published by American Chemical Society).
}

Date of initial receipt: 19 June 1993

Date of acceptance: 9 August 1993

Ms 135SR-165 